\title{
Tax Reform and Economic Growth in Developing Countries: The Trade Openness and Public Revenue Channels
}

SENA KIMM GNANGNON ( $\square$ kgnangnon@yahoo.fr )

\section{Research}

Keywords: Tax reform, Trade openness, Public Revenue, Developing countries

Posted Date: February 18th, 2020

DOl: https://doi.org/10.21203/rs.2.23798/v1

License: (c) (i) This work is licensed under a Creative Commons Attribution 4.0 International License.

Read Full License 


\section{Tax Reform and Economic Growth in \\ Developing Countries: The Trade Openness and Public Revenue Channels}

Corresponding Author: Sèna Kimm GNANGNON, Economic Affairs Officer

Affiliation: World Trade Organization

Postal Address: Rue de Lausanne 154, CH-1211 Geneva 21, Switzerland.

E-mail: kgnangnon@yahoo.fr

Other Emails: SenaKimm.Gnangnon@wto.org / kignangnon@gmail.com 


\title{
Tax Reform and Economic Growth in \\ Developing Countries: The Trade Openness and Public Revenue Channels
}

\begin{abstract}
The current article examines the economic growth effect of tax reform in developing countries. Tax reform is defined here as the process that entails the convergence of developing countries' tax structure towards that of developed countries. The analysis covers a sample of 92 developing countries over the period 1980-2015. The empirical results have shown that tax reform promotes economic growth, including when governments are able to collect a minimum level of public revenue-to-GDP ratio and when they further open-up their economies to international trade. These findings have an important policy implication.
\end{abstract}

Keywords: Tax reform; Trade openness; Public Revenue; Developing countries. JEL Classification: F43; H20. 


\section{Introduction}

Developing countries face serious challenges in raising public revenue for achieving development goals when further opening-up their economies to international trade. In particular, the high dependence of these countries total public revenue, including tax revenue, on international trade tax revenue is prejudicial to public revenue in the medium-to-long term. The unavoidable process of trade liberalization either through multilateral trade agreements under the auspices of the World Trade Organization (WTO) or through regional or bilateral trade agreements would likely further erode international trade tax revenue, and consequently public revenue in the medium to long term. Some studies (e.g., Cagé and Gadenne, 2018; Gnangnon and Brun, 2019; Khattry, 2003; Khattry and Rao, 2002) have demonstrated empirically that trade openness (or trade policy liberalization) exerts a negative effect on public revenue, including tax revenue in developing countries. It is against this background that international financial institutions pioneered by the International Monetary Fund (IMF) and the World Bank have advised policymakers in developing countries to undertake a tax reform that would ultimately help reduce the dependence of their tax structure on international trade tax revenue in the medium-to the long term. This reform, which therefore, involves a heavy reliance on domestic tax revenue, is also referred in the literature to as 'tax transition reform' (e.g., Brun and Chambas, 2014; Chambas, 2005; Gnangnon and Brun, 2019a, 2019b). The tax reform advised by the IMF and the World Bank entails a proportional tariff reduction combined with a point-by-point consumption tax increase (i.e., a revenue neutral tarifftax reforms). The argument underlying the implementation of the revenue neutral tariff-tax reforms is that such a reform leaves the consumer prices unchanged, and only affects the production sector of the economy. This would, therefore, help allocate more efficiently resources in the production sector, and ultimately result in a production efficiency-driven welfare gain. At the same time, lower production subsidies would unambiguously result in higher public revenue (e.g., Kreickemeier and Raimondos-Møller, 2008). Many studies (e.g., Fujiwara, 2013; Ganelli and Tervala, 2015; Hatzipanayotou et al. 1994; Karakosta and Tsakiris, 2014; Keen and Ligthart, 2002; Keen and Ligthart, 2005; Kreickemeier and Raimondos-Møller, 2008; Naito, 2006) have subsequently looked at the macroeconomic effects of revenue neutral tariff-tax reforms, notably on public revenue, welfare, economic growth and market access.

The current article aims to complement these studies by investigating the effect of tax reform on economic growth, where the concept of tax reform is defined in a different way, although in closed spirit to the idea of revenue neutral tariff-tax reform. Following Gnangnon and Brun (2019a, 2019b) and Gnangnon (2019), tax reform is considered as the process involving the 
convergence of a developing country's tax structure towards developed countries' tax structure which is highly less dependent on international trade tax revenue but rather heavily dependent on domestic tax revenue. The resulting indicator of tax reform is used to test empirically the effect of tax reform on economic growth. In particular, we assess whether this effect takes place through the trade openness and public revenue channels, in light of the findings by Gnangnon and Brun (2019a) that tax reform enhanced public revenue in developing countries, and by Gnangnon (2019) that tax reform promotes trade openness in developing countries. The empirical analysis uses an unbalanced panel dataset of 92 developing countries over the period 1980-2015. Results, based on the two-step system Generalized Methods of Moments (GMM) estimator, suggest that tax reform promotes economic growth in developing countries, including through the trade openness and public revenue channels.

The rest of the paper is organized as follows. Section 2 lays out a theoretical discussion on how tax reform could affect economic growth. Section 3 posits the model specification that would allow addressing the questions raised above, and discussed the econometric method used to estimate this model. Section 4 analyses empirical results, and section 5 concludes.

\section{Theoretical discussion}

The theoretical literature that has examined the macroeconomic effects of tariff-tax reforms has concluded that these reforms enhance welfare in perfectly competitive environments, but not necessarily under imperfect competition. The first formalization of the economic effects of tarifftax reforms was performed by Michael et al. (1993) who have relied on a static trade model of a small open economy, and introduce revenue concerns into an analysis of infinitesimal tariff reforms. They have shown that a revenue-neutral tariff-tax reform increases welfare under fairly general conditions. Hatzipanayotou et al. (1994) have developed a model with a competitive small open economy, and found a welfare improving effect of the revenue neutral tariff-tax reform. Keen and Ligthart (2002) have generalized this result, but the same authors have in 2005 (Keen and Ligthart, 2005) demonstrated that this theoretical result does not hold under imperfect competition, i.e., in the context of an international Cournot duopoly with a domestic and a foreign firm and where there exists linear demand and marginal costs. In fact, Keen and Ligthart (2005) have shown that unilateral coordinated tariff-tax reforms (revenue-neutral tariff-tax reform) reduces national welfare. This is because lower import tariffs combined with a rise in the consumption tax shifts rents from the imperfectly competitive domestic firm to the foreign firm, and the negative effect on domestic profits would more than offset the rise in public revenue. 
Naito and Abe (2008) have extended the theoretical analysis of Keen and Ligthart (2005) by taking into account intermediate goods. They have then examined the effects of tariff and consumption tax reform policies on welfare and revenue, when tariffs apply to both final and intermediate goods. Their theoretical results, under plausible conditions, are that reform policies that lead to lower total tax burden on intermediate goods, while either leaving the total tax burden on the final good unchanged or changing the total tax burden on the final good so as to keep government revenue neutral, improve both national welfare and public revenue.

An important finding of the theoretical work by Karakosta and Tsakiris (2014) has also been that under an imperfectly competitive framework with differentiated products, tariffs-tax reforms policies involving a tariff cut combined with an equal increase in the consumption tax, on the one hand, and a tariff cut combined with an increase in the consumption tax that leaves the consumer price of the imported good unchanged, on the other hand, reduce welfare for any degree of product differentiation. However, these reforms could be welfare-enhancing when firms compete over prices rather than over quantities, and if the degree of product differentiation is sufficiently low. Along the same lines, Fujiwara (2013) has shown that under imperfect competition (in particular decreasing marginal costs), the revenue-neutral tariff-tax reform generates higher public revenue, improves market access and enhances welfare. Additionally, the author has demonstrated that the theoretical result by Keen and Ligthart (2005) is valid under increasing marginal costs. Naito (2006) has used a two-good, two-factor endogenous growth model to investigate theoretically the effects of tariff-tax reform on economic growth, public revenue and welfare. His findings indicate, inter alia, that a combination of consumer-price-neutral tariff and tax reform for growth enhancement with an additional rise in the consumption tax on the less distorted good could result in higher economic growth, higher public revenue, and welfare gains. The author has then recommended that irrespective of the direction of the effect of trade liberalization on economic growth, policymakers should implement tariff and tax reform that simultaneously improves growth, revenue, and welfare. In a model of a competitive small open economy, Kreickemeier and Raimondos-Møller (2008) have provided theoretical evidence that the point-bypoint policy reform might not necessarily generate greater market access (i.e. higher import value). However, under slightly stronger assumptions, some other types of tariff-tax reforms could increase welfare, public revenue and market access. In the same vein, Emran and Stiglitz (2005) have used an extension of a standard static trade model to allow for incomplete coverage of the consumption tax due to an informal sector. They have shown that revenue-neutral tariff-tax reforms reduce welfare under plausible conditions. Ganelli and Tervala (2015) have demonstrated theoretically that the effect of a unilateral revenue-neutral tariff-tax reform on welfare translates 
through the terms-of-trade channel: as lower domestic tariff deteriorates the domestic terms of trade, and hence induces a rise in the price paid by domestic residents for their imports, it would adversely affect national welfare. This finding contrasts with the bulk of previous studies that have found a welfare-enhancing effect of revenue-neutral tariff-tax reform. Overall, the theoretical effect of the revenue-neutral tariff-tax reforms is mixed, although many studies have found that literature under perfectly competitive conditions, such a reform could enhance welfare, but under imperfect competition the welfare effect might be different, while market access could improve.

A tax reform that involves the convergence of a developing country's tax structure towards developed countries' tax structure is well closed in the spirit to the revenue-neutral tariff tax reform. In light of the previous literature review, we argue that such a tax reform could be positively associated with economic growth, and this leads us to expect in the empirical analysis a positive effect of our indicator of tax reform on economic growth. Tax reform could also influence economic growth through trade openness. Gnangnon (2019) has provided empirical evidence that tax reform that involves the convergence of the tax structure towards that of developed countries leads to greater trade openness in developing countries, with Least developed countries (LDCs) enjoying a higher positive effect than non-LDCs do. In that context, we argue that the direction of the effect of tax reform on economic growth that translates through trade openness would depend on the effect of trade openness itself on economic growth. A voluminous literature ${ }^{1}$ has been devoted to the economic growth effect of trade openness. It seems now well admitted that greater trade openness is positively associated with economic growth, in particular if trade policy measures are accompanied with other appropriate policies and measures to offset the eventual adverse effects of trade policy on the domestic economy. For example, Chang et al. (2009) have shown empirically that trade openness could be economic growth enhancing if it was accompanied by structural policies in various areas such as educational investment, financial depth, inflation stabilization, public infrastructure, governance, labour market flexibility, ease of firm entry, and ease of firm exit. Other studies have reported empirical evidence of a positive effect of trade openness on economic growth, in particular for countries specialized in high quality export products (e.g., Camarero et al., 2015; Chang et al. 2009; Christiansen et al. 2013; Falvey et al., 2012; Huchet-Bourdon et al., 2018; Kneller et al., 2008; Onafowora and Owoye, 1998; Panagariya, 2004; Yanikkaya, 2003). From the theoretical perspective, the neoclassical approach has postulated that countries' comparative advantage determines their trade patterns: to maximize its welfare, each country should produce and export the goods in which it has lower relative unitary costs compared to its competitors. This, therefore, signifies that the country should specialize on exports activities in which it is the most economically efficient. In such a case, the gains from trade may be either 
static (i.e., when they arise from better efficiency in allocation of resources) or dynamic through imported technology or learning-by-doing effects. Thus, according to the neoclassical theory, greater trade openness does not result in a higher economic growth rate in the long-run, but only to a rise in the income level (see Camarero et al. 2015). The second strand of the theoretical literature that has considered the relationship between trade openness and economic growth is the endogenous growth theory. It has posited that trade openness could affect both the level of income and the long-run economic growth through scale, allocation, spillover and redundancy effects. Scale effects arise from the closer integration of an economy to the world market (e.g., Alesina et al., 2005), while allocation effects stem from the accumulation of production factors, including human or physical capital or Research and Development, which benefit to those sectors that intensively use these factors (e.g., Melitz, 2003). Spillover effects are explained by the diffusion of new knowledge effects of trade openness (e.g., Grossman and Helpman, 2015): for example, higher access to imported capital goods that embody technology could facilitate the diffusion of knowledge and strongly influence economic growth. The third strand of the theoretical literature on trade openness and economic growth has pointed out the role of institutions in ensuring that trade openness promotes economic growth. Although this theoretical literature has not explicitly incorporated institutions in the growth theory, it has postulated that without basic institutions such as law and order, well-defined property rights, and impartially enforced contracts - trade openness could not promote economic growth. Against this background, we postulate that if trade openness promotes economic growth, and as tax reform could be conducive to greater trade openness (e.g., Fujiwara, 2013; Gnangnon, 2019), a higher extent of tax reform would enhance economic growth as the degree of trade openness would rise. In contrast, if trade openness results in lower economic growth, then greater extent of tax reform will increase economic growth only for countries that reduces their degree of trade openness.

We now discuss how tax reform could influence economic through a second channel, including public revenue. The above-mentioned literature on the effect of the revenue-neutral tariff tax reforms tends to conclude that the point-by-point policy reform is positively associated with economic growth. Gnangnon and Brun (2019a) have shown that the tax reform that entails the convergence of a developing country's tax structure towards developed countries' tax structure generates higher tax revenue in developing countries. In the same vein, other studies such as Baunsgaard and Keen (2010), Crivelli (2016) and Waglé, 2011 have reported empirical evidence that developing countries have been able to recoup from other sources (including domestic sources) the trade tax revenue they have lost further to trade liberalization. In spite of the findings of a positive effect of tax reform on public revenue, one might not systematically conclude that 
tax reform would translate into higher economic growth in developing countries as the public revenue rises. This is because if it translates through the public revenue channel, the economic growth effect of tax reform would ultimately depend on how the public revenue itself influences economic growth. The literature on the effect of public revenue on economic growth has been inconclusive. According to the neoclassical growth model of Solow (1956) and Swan (1956), tax policy does not affect the steady state growth, i.e., the long run economic growth. In contrast, the endogenous growth theory (e.g., Romer, 1990) has developed models in which government spending and tax policies can have long term or permanent growth effects. Taxation could negatively affect economic growth through the associated distortions in choices and effects of discouragement factors inherent in taxes (e.g., Easterly and Rebelo, 1993). Likewise, taxation could enhance economic growth indirectly through the expenditures financed by the taxation (e.g., Engen and Skinner, 1996). Some recent studies have reported empirical evidence that low tax rates are positively associated with economic growth (e.g., Angelopoulos et al., 2007; Lee and Gordon, 2005; Romer and Romer, 2010), while others have shown that higher tax rates are likely to promote economic growth (e.g., Padovano and Galli, 2001; Piketty et al. 2011). Some other studies emphasize that different types of tax could affect differently economic growth (e.g., Attinasi and Klemm, 2016; Lu, 2015; McNabb, 2018; Miller and Russek 1997; Myles 2000). According to Myles (2000), the exact nature of the taxation-growth linkages is an empirical matter. For example, Miller and Russek (1997) have found, inter alia, that tax-financed increases in public expenditure stimulate growth in developing countries. Myles (2000) has shown evidence that the economic growth effect of tax is very weak. McNabb (2018) has obtained for developing countries that revenue-neutral increases in income taxes result in lower long-run GDP growth, and revenue-neutral reductions in trade taxes have not always had positive effects. Nevertheless, the author has indicated that these outcomes vary according to the income level. he has therefore called into question the validity of existing findings on the matter for developing countries.

Overall, tax reform would promote economic growth through the public revenue channel if public revenue itself generates higher economic growth, and in a such a case, the higher the public revenue collected, the greater is the effect of tax reform on economic growth. In contrast, if higher public revenue induces lower economic growth, then the effect of tax reform on economic growth through the public revenue channel would likely be negative. The extent to which the effect of tax reform on economic growth would depend on public revenue is ultimately an empirical matter. 


\section{Empirical strategy}

This section firstly presents the model specification that would allow examining the effect of tax reform on economic growth, including through the public revenue and trade openness channels (see Sub-section 3.1). Secondly, it discusses the econometric methodology to estimate the model (see Sub-section 3.2).

\subsection{Model specification}

To estimate the effect of tax reform on economic growth, we postulate a model specification that includes a number of well-known standard determinants of economic growth - as identified in the economic growth literature - that could affect here the effect of tax reform on economic growth - along with the tax reform indicator, which we describe below. The standard determinants of economic growth considered include: the gross fixed capital formation as a share of GDP (which measures the level of domestic investment), denoted "GFCF"; the human capital accumulation (proxied by the average education level), denoted "EDU"; the inflation rate, denoted "INFL"; the financial development depth, denoted "FINDEV"; the institutional quality, denoted "POLITY2" and the total population size, denoted "POP".

The model postulated is as follows:

$$
\begin{aligned}
& \text { GROWTH }_{i t}=\alpha_{0}+\alpha_{1} \text { GROWTH }_{i t-1}+\alpha_{2} \text { TAXREF }_{i t}+\alpha_{3} \text { GFCF }_{i t}+\alpha_{4} \text { EDU }_{i t}+\alpha_{5} \text { FINDEV }_{i t}+ \\
& \alpha_{6} \text { INFL }_{i t}+\alpha_{7} \text { POLITY }_{i t}+\alpha_{8} \log (\text { POP })_{i t}+\mu_{i}+\gamma_{t}+\omega_{i t}
\end{aligned}
$$

The subscripts $\mathrm{i}$ and $\mathrm{t}$ indicate respectively the country and the time-period. To estimate model (1), we use an unbalanced panel dataset containing 92 developing countries over the period 1980-2015, selected on the basis of data availability. In particular, we consider as developing countries those not classified as High-Income Countries by the World Bank. We have also followed the practice in the empirical literature to dampen the effect of business cycles on variables by using non-overlapping sub-periods of 5-year average data. The sub-periods include 1980-1984; 1985-1989; 1990-1994; 1995-1999; 2000-2004; 2005-2009 and 2010-2015. $\alpha_{0}$ to $\alpha_{8}$ are parameters to be estimated. $\mu_{i}$ are countries' time invariant fixed effects; $\gamma_{t}$ are time dummies capturing shocks that affect together all countries' economic growth patterns. $\omega_{i t}$ is a well-behaving error term.

The dependent variable "GROWTH" is the real economic growth rate (constant 2010 US\$ prices). The one-period lag of the dependent variable has been introduced in model (1) as a righthand side regressor in order to capture the state-dependence path of economic growth as well as to control for possible omitted variables in the model specification. The key variable of interest in the analysis is the tax reform indicator. Following Gnangnon (2019), Gnangnon and Brun (2019a, 
2019b), our indicator of tax reform reflects the convergence of the tax structure of a given developing country towards the developed countries' tax structure. It has been computed using the semi-metric Bray-Curtis dissimilarity index (Bray \& Curtis, 1957) as follows: $d_{i t}=$

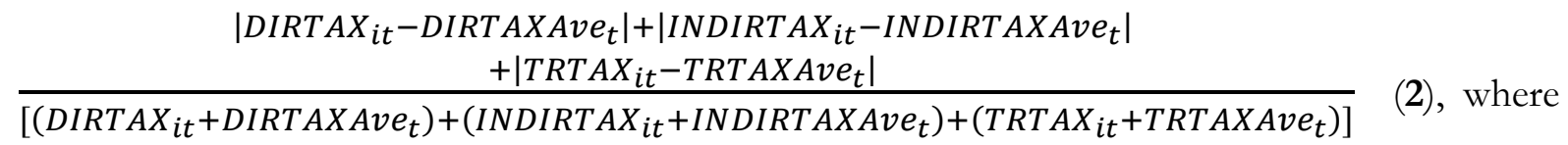
$d_{i t}$ represents the dissimilarity index between a given developing country's tax structure (for a given year) and the tax structure of developed countries. DIRTAX, INDIRTAX, and TRTAX stand respectively for the direct tax revenue ratio, the indirect tax revenue ratio, and the trade tax revenue ratio for a given developing country in a year t. For developed countries ${ }^{2}$, DIRTAXAve, INDIRTAXAve, and TRTAXAve are respectively the average (over all developed countries, in a given year) of the direct tax revenue ratio; the indirect tax revenue ratio; and the trade tax revenue ratio. For each of these tax revenue variables, we have excluded the natural resource revenue components (for further details, see Gnangnon, 2019, Gnangnon and Brun, 2019a, 2019b). The indicator of tax reform for a given developing country in a given year, is defined as TAXREF $=\left(1-d_{i t}\right) * 100$. Its values range between 0 and 100 , with a rise in these values reflecting greater tax structure convergence, i.e., greater extent of tax reform. Inversely, lower values of this index reflect a lower extent of tax reform, that is, a divergence between the tax structure of developing countries and the tax structure of developed countries.

Note that as we are testing the effect of tax reform on economic growth through trade openness and public revenue, these two variables have not been included in the baseline model (1). Appendix 1 describes all other variables used in the analysis, and Appendix 2 reports descriptive statistics on these variables, and Appendix 3 lists countries used in the analysis.

\subsection{Econometric strategy}

To estimate model (1), we use the popular two-step system Generalized Methods of Moments (GMM) estimator proposed by Arellano and Bover (1995) and Blundell and Bond (1998) for dynamic panels with a small-time dimension and large cross-section. While this estimator has been typically used in empirical analyses using microeconomic panel datasets, it is also widely used now in macro-empirical analyses, including in studies on the determinants of economic growth (e.g., Chang et al. 2009; Christiansen et al. 2013; Gnangnon, 2018; Huchet-Bourdon et al. 2018).

This estimator has the advantage of allowing to estimate a dynamic model (with the lagged dependent variable as a regressor), while helping tackle various endogeneity issues. Specifically, the two-step system GMM estimator helps deal with the Nickell bias (Nickell, 1981) due to the 
correlation between the one-period lag of the dependent variable (as a regressor) and countries' time-invariant specific effects, omitted variables biases, as well as the endogeneity concerns associated with the bi-directional causality between regressors and the dependent variable. This estimator combines the first-difference equations with suitably lagged levels as instruments and levels equations with appropriate lagged first-differences as instruments. It is more efficient than the first-differenced GMM estimator of Arellano and Bond (1991) in the presence of persistent data and weak instruments for first differences GMM, and when the panel dataset is unbalanced (as in this case, the difference GMM estimator has a weakness of magnifying gaps - see Roodman, 2009). In the present analysis, we have considered as endogenous the following tax reform, education level, inflation, gross fixed capital formation, financial development and institutional quality, in light of the potential reverse causality associated with them.

The empirical analysis based on the two-step system GMM approach goes as follows. We first estimate the baseline model (1) and report the results obtained in column [1] of Table 1.

Second, we examine whether the effect obtained over the full sample is the same over subsamples of low-income countries (LICs), lower-middle income countries (LMICs) and uppermiddle income countries (UMICs), based on the World Bank's classification of countries. To perform this empirical exercise, we define dummy variables, namely LIC, LMIC, and UMIC respectively for each of these categories (each dummy variable takes the value 1 if a country belongs to the relevant category, and 0, otherwise). Each dummy and its interaction with the tax reform indicator are then introduced in model (1). The outcomes of the resulting three specifications of model (1) are presented in columns [2] to [4] of Table 1.

Table 2 contains the outcomes of the estimation of different variants of model (1) that allow examining the channels (trade openness and public revenue) through which tax reform could affect economic growth. The first key channel-variable of interest is the degree of trade openness, denoted "OPENSW". This is the indicator of trade openness proposed by Squalli and Wilson (2011), which is computed as a composite indicator of the traditional indicator of trade openness (i.e., the sum of exports and imports of goods and services as a share of GDP) adjusted by the proportion of a country's trade level relative to the average world trade (see Squalli and Wilson, 2011: p1758). This variable genuinely reflects the level of a country's participation in global trade, including their integration into the international trade market. It is our primary measure of trade openness. For robustness check, we also use the standard measure of trade openness, that is the sum of exports and imports of goods and services as a share of GDP, denoted "OPEN". The second key channel-variable of interest is the total public revenue, denoted "REVENUE". It is the overall public revenue collected by a given country (including tax revenue and non-tax revenue), 
but excluding grants and social contributions, and expressed as a share of GDP. To investigate whether the effect of tax reform on economic growth depends on the level of trade openness, we estimate two different variants of model (1) in which we introduce the trade openness variable (either "OPENSW" or "OPEN") along with the interaction of this variable with the tax reform indicator. It is worth highlighting that the natural logarithm has been applied to the variable "OPENSW" in model (1) so as to reduce its high skewness, whereas it has not been applied to the variable "OPEN" when introduced in model (1). The results of these estimations are presented in columns [1] and [2] of Table 2. Additionally, we explore whether the effect of tax reform on economic growth depends on the share of the total public revenue-to-GDP ratio by estimating another specification of model (1) in which we include both the variable "REVENUE" as well as its interaction with the tax reform variable. The results of these estimations are reported in column [3] of Table 2.

\section{Analysis of empirical results}

Before considering the estimations' outcomes displayed in Tables 1 and 2, we need to ensure the suitability of the two-step system GMM estimator for conducting the empirical analysis. The diagnostic tests that allow assessing the consistency of the two-step system GMM estimator are presented in Appendix 4. As noted in this Appendix, the outcomes of all diagnostic tests are fully satisfactory, and therefore suggest the validity of the two-step system GMM estimator for conducting the empirical analysis.

We now turn to results presented in Table 1. We note from column [1] that the coefficient of the tax reform variable is positive and significant at the $1 \%$ level, thereby suggesting that tax reform exerts a positive and significant effect on economic growth over the full sample. In particular, a 1-point increase in the index of tax reform is associated with a 0.076 percentage point increase in the economic growth rate. In a more economic sense, an increase in the index of tax reform by a one standard deviation (which amounts to 15.377 - see Appendix 2) results in a 1.17 percentage point $\left(=0.0758^{*} 15.377\right)$ increase in economic growth rate. Results concerning control variables indicate a positive and significant effect of investment (measured by the gross fixed capital formation variable) and the population size on economic growth, and a negative and significant effect of inflation and financial development on economic growth. The coefficients of the education and institutional quality variables are not statistically significant at the conventional levels. As noted above, the results reported in columns [2] to [4] allow assessing the net effect of tax reform on economic growth over the sub-samples LICs, LMICs, and UMICs. We obtain that 
at the $5 \%$ level, the net effect of tax reform on economic growth in LICs, LMICs and UMICs amount respectively to $0.012(=0.0994-0.0866) ; 0.0536$ and 0.0639 . These three outcomes, therefore, suggest that the highest magnitude of the effect of tax reform on economic growth accrues to UMICs, followed by LMICs, and LICs. A meaningful interpretation of these outcomes could be that an increase in the index of tax reform by a one standard deviation is associated with a 0.18 percentage point $(=0.012 * 15.377)$ increase in economic growth rate in LICs, a 0.82 percentage point $(=0.0536 * 15.377)$ increase in economic growth rate in LMICs, and a 0.98 percentage point $(=0.0639 * 15.377)$ rise in economic growth rate in UMICs.

Turning now to estimates reported in Table 2, we note, with few exceptions, that results concerning control variables are in line with those in Table 1. Across the three columns of this Table, our key coefficients of interest include the coefficient of "TAXREF" and the interaction terms related to the interaction variables. In particular, we observe in column [1] that the coefficient of "TAXREF" and the interaction term of the variable ("TAXREF*[Log(OPENSW)]") are both positive and statistically significant at the $1 \%$ level. Taken jointly, these two results suggest that regardless of the level of trade openness ("OPENSW"), tax reform always exerts a positive and significant effect on economic growth, and the higher the degree of trade openness, the greater is the magnitude of the positive effect of tax reform on economic growth. These findings are confirmed in Figure 1, which shows at the 95 per cent confidence intervals, the marginal impact of tax reform on economic growth rate for varying levels of trade openness, measured by the indicator "OPENSW". The statistically significant marginal impacts at the 95 per cent confidence intervals are those encompassing only the upper and lower bounds of the confidence interval that are either above or below the zero line. This Figure shows that the marginal impact of tax reform on economic growth is always positive and statistically significant, and additionally increases as countries' level of trade openness rises. This, therefore, suggests that irrespective of the level of trade openness, tax reform always promotes economic growth, and the magnitude of this positive impact rises as countries further open-up their economies to international trade.

Results in column [2] indicate a negative coefficient of "TAXREF" and a positive interaction term of the variable ("TAXREF*OPEN"), with both coefficients being statistically significant at the $1 \%$ level. The combination of these two results suggest that the total effect of tax reform on economic growth over the full sample changes sign, and particularly becomes positive after a turning point of the degree of trade openness. This turning point amounts to $37.1 \%$ (= $0.0382 / 0.00103)$. Thus, on average, countries whose degree of trade openness ("OPEN") is lower than $37.1 \%$ experience a negative and significant effect of tax reform on economic growth, while those with a level of trade openness higher than $37.1 \%$ enjoy a positive and significant effect of 
tax reform on economic growth. In particular, for the latter group of countries, the higher the level of trade openness, the greater is the magnitude of the positive effect of tax reform on economic growth. Figure 2 provides a better picture on these impacts, by showing at the 95 per cent confidence intervals, the marginal impact of tax reform on economic growth rate for varying levels of trade openness, measured by the indicator "OPEN". The pattern observed in this Figure is similar to the one in Figure 1. Figure 2 shows that the marginal impact of tax reform on economic growth rate increases as countries enjoy greater trade openness. However, it could be positive or negative, and is not always statistically significant. In particular, it is not statistically significant for levels of trade openness higher than $23.16 \%$, but strictly lower than $50.7 \%$. Countries whose degree of trade openness is lower than $23.16 \%$ experience a negative effect of tax reform on economic growth. In contrast, countries whose level of trade openness is higher than (or equal to) $50.7 \%$ enjoy a positive effect of tax reform on economic growth, and for these countries, the greater the level of trade openness, the higher is the size of the positive effect of tax reform on economic growth. Overall, both Figures 1 and 2 convey the message that the magnitude of the positive effect of tax reform on economic growth increases as countries further open-up their economies to international trade.

We now turn to estimates in column [3] of Table 2, which suggest a negative coefficient of "TAXREF" and a positive interaction term of the variable ("TAXREF*REVENUE"), with both coefficients being statistically significant at the $1 \%$ level. jointly considered, these two results suggest that the total effect of tax reform on economic growth over the full sample changes sign, and particularly becomes positive after a turning point of the share of total public revenue in GDP. This turning point amounts to $12.5 \%(=0.0702 / 0.00560)$. Thus, countries with a total public revenue to-GDP-ratio lower than 12.5\% experience a negative effect of tax reform on economic growth. Countries whose total public revenue-to-GDP ratio exceeds $12.5 \%$ experience a positive effect of tax reform on economic growth, and for these countries, the higher the total public revenue-to-GDP ratio, the greater is the size of the positive effect of tax reform on economic growth. Figure 3 display, at the 95 per cent confidence intervals, the marginal impact of tax reform on economic growth rate for varying shares of total public revenue in GDP. It suggests that this marginal impact rises as countries experience a higher share of total public revenue in GDP. However, it could take both positive and negative values, and is additionally not always statistically significant. Specifically, it is not statistically significant for values of the total public revenue toGDP ratio higher comprised between than $14.4 \%$ and $20.45 \%$ (strictly lower than $20.45 \%$ ). In other words, countries whose share of total public revenue in GDP ranges between $14.4 \%$ and $20.45 \%$ experience no significant effect of tax reform on economic growth. However, in countries 
whose total public revenue to-GDP ratios is lower than $14.4 \%$, tax reform influences negatively and significantly economic growth. Conversely, countries that enjoy a total public revenue to-GDP ratios higher than $20.45 \%{ }^{3}$ experience a positive effect of tax reform on economic growth, and the the increase in this share induces a higher positive effect of tax reform on economic growth. Overall, this Figure conveys the message tax reform influences positively economic growth only when the total public revenue to GDP ratio generated exceeds a certain level $(20.45 \%)$. This minimum threshold of total public revenue-to-GDP ratio seems reasonable to the extent that Gaspar et al. (2016) have explored empirically whether there is a minimum tax revenue-to-GDP ratio associated with a significant acceleration in the process of growth and development, and documented the existence of a tipping point at about $12^{3 / 4}$ percent of GDP.

\section{Conclusion}

The current article has provided empirical evidence that tax reform promotes economic growth in developing countries, with upper middle-income countries enjoying the highest positive effect of tax reform on economic growth, followed by lower-middle income countries, and lowincome countries. Interestingly, results show that greater trade openness enhances the positive effect of tax reform on economic growth in developing countries, because the magnitude of this positive effect increases as countries further open-up their economies to international trade. Last but not least, the effect of tax reform on economic growth also depends on the level of public revenue collected, as tax reform fosters economic growth only when the total public revenue-toGDP ratio exceeds the minimum threshold of $20.45 \%$. This minimum threshold of the total public revenue-to-GDP ratio appears to be consistent with the suggestion by the IMF that the tipping point about which tax revenue-to-GDP ratio can promote economic growth and development is 13 percent. The key policy implication of this analysis is that policymakers in developing countries should pursue tax reform - with a view to reducing their public revenue dependence on international trade tax revenue - while concurrently further opening up their economies to international trade. These ultimately enhance economic growth. 


\section{Endnotes}

1. For example, Singh (2010) has provided a literature survey on the economic growth effect of trade openness.

2. The list of developed countries (Old Industrialized countries) used to compute the index of convergence in tax structure index for developing countries in the analysis includes: Australia, Austria, Belgium, Canada, Denmark, Finland, France, Germany, Greece, Japan, Luxembourg, Netherlands, New Zealand, Norway, Portugal, Spain, Sweden and Switzerland.

3. According the IMF (IMF, 2009: page 15), the appropriate level of taxation depends on country characteristics, and many low-income developing countries have increased their tax revenue share of GDP from 12 per cent in the early 2000s to nearly 15 per cent today. The median tax revenueto-GDP collection has reached 15 percent and 18 percent respectively in low-income developing countries and emerging market economies. 


\section{Declaration statements}

\section{Availability of data and material}

Data and material would be made available upon request.

\section{Competing interests}

I have not provided any comments on articles published in the Journal of Economic Structures. Therefore, there is no financial competing and Non-financial competing interests relating to any comments provided on the Journal of Economic Structures. Additionally, I hereby confirm that there are no potential conflicts of interest relating to this paper apart from the Disclaimer included in the "Acknowledgements" below. The paper does not require any "Informed Consent".

\section{Funding}

This work has not received any financial support.

\section{Author's contribution}

The Author drafts alone all sections of the paper.

\section{Acknowledgments}

This paper represents the personal opinions of individual staff members and is not meant to represent the position or opinions of the WTO or its Members. The author would like to express their sincere gratitude to the anonymous Reviewers for their useful comments on an earlier version this article. Any errors or omissions are the fault of the author.

\section{Author's information (optional)}

Kimm Gnangnon is Economist at the World Trade Organization, in Geneva, Switzerland. 


\section{References}

Alesina, A, Spolaore, E, Wacziarg, R. (2005). Trade, growth and the size of countries. In Aghion, P., Durlauf, S. (Eds.), Handbook of economic growth, (pp. 1499-1542). Amsterdam: Elsevier.

Angelopoulos, K., Economides, G., and Kammas, P. (2007). Tax Spending Policies and Economic Growth: Theoretical Predictions and Evidence from the OECD. European Journal of Political Economy, 23, 885-902.

Arellano, M., and Bond, S. (1991). Some Tests of Specification for Panel Data: Monte Carlo Evidence and an Application to Employment Equations. Review of Economic Studies, 58, 277 297.

Arellano, M., and Bover, O. (1995). Another look at the instrumental variable estimation of errorcomponents models. Journal of Econometrics, 68 (1), 29-51.

Attinasi, M.G., and Klemm, A. (2016). The growth impact of discretionary fiscal policy measures. Journal of Macroeconomics, 49, 265-279.

Baunsgaard, T., and Keen, M. (2010). Tax Revenue and (or?) Trade Liberalization. Journal of Public Economics, 94(9-10), 563-577.

Bray, J.R., and Curtis, J.T. (1957). An ordination of the upland forest communities of Southern Wisconsin. Ecological Monographies 27, 325-349.

Brun, J-F., and Chambas, G. (2014). How do tax systems transform as countries structurally transform themselves? Background Paper for the European Development Report 2015, Overseas Development Institute (ODI), London.

Cagé, J., and Gadenne, L. (2018). Tax revenues and the fiscal cost of trade liberalization, 17922006, 1792-2006. Explorations in Economic History, 70, 1-24.

Camarero, M., Martínez-Zarzoso, I., Nowak-Lehmann, F., and Tamarit, C. (2015). Trade Openness and Income: A Tale of Two Regions. The World Economy, 39(3), 386-408.

Chambas, G. (2005). Afrique au sud du sahara: quelle stratégie de transition fiscale? Afrique Contemporaine (1), 133-163.

Chang, R., Kaltani, L., and Loayza, N.V. (2009). Openness can be good for growth: The role of policy complementarities. Journal of Development Economics, 90(1), 33-49.

Christiansen, L., Schindler, M., and Tressel, T. (2013). Growth and structural reforms: A new assessment. Journal of International Economics, 89(2), 347-356.

Crivelli, E. (2016). Trade liberalization and tax revenue in transition: an empirical analysis of the replacement strategy. Eurasian Economic Review, 6,1-25.

Easterly, W., and Rebelo, S. (1993). Fiscal policy and economic growth. Journal of Monetary Economics, 32, 417-458. 
Emran, M. S., and Stiglitz, J. E. (2005). On Selective Indirect Tax Reform in Developing Countries. Journal of Public Economics, 89(4), 599-623.

Engen, E. M., and Skinner, J. (1996). Taxation and economic growth, National Tax Journal, 49, 617-642.

Falvey, R., Foster, N., and Greenaway, D. (2012). Trade Liberalization, Economic Crises, and Growth. World Development, 40(11), 2177-2193.

Fujiwara, K. (2013). A Win-Win-Win Tariff-Tax Reform under Imperfect Competition. Review of International Economics, 21(5), 857-867.

Ganelli, G., and Tervala, J. (2015). Tariff-tax Reforms in Large Economies. The World Economy, 38(12), 1990-2012.

Gnangnon, S.K. (2018). Multilateral Trade Liberalization and Economic Growth. Journal of Economic Integration, 33(2), 1261 1301.

Gnangnon, S.K. (2019). Tax Reform and Trade Openness in Developing Countries. Journal of Economic Integration, 34(3), 498-519.

Gnangnon, S.K., and Brun, J-F. (2019a). Trade openness, tax reform and tax revenue in developing countries. The World Economy, https://onlinelibrary.wiley.com/doi/full/10.1111/twec.12858

Gnangnon, S.K., and Brun, J-F. (2019b). Tax Reform and Public Revenue Instability in Developing Countries: Does the Volatility of Development Aid Matter? Journal of International Development, https://onlinelibrary.wiley.com/doi/abs/10.1002/jid.3436?af $=\mathrm{R}$

Grossman, G.M., and Helpman, E. (2015). Globalization and growth. American Economic Review, 105(5), 100-104.

Hatzipanayotou, P., Michael, M.S., and Miller, S.M., 1994. Win-win indirect tax reform: a modest proposal. Economics Letters, 44, 147-151.

Huchet-Bourdon, M., Le Mouël, C., and Vijil, M. (2018). The relationship between trade openness and economic growth: Some new insights on the openness measurement issue. The World Economy, 41(1), 59-76.

International Monetary Fund (2019). Fiscal Policy and Development: Human, Social, and Physical Investment for the SDGs. IMF Staff Discussion Note 19/03, Washington, D.C.: International Monetary Fund.

Karakosta, O., and Tsakiris, N. (2014). Can tariff and tax reforms deliver welfare improvements under imperfect competition?, The Journal of International Trade \& Economic Development, 23(3), 315-328.

Keen, M., and Ligthart. J.E. (2005). Coordinating tariff reduction and domestic tax reform under imperfect competition. Review of International Economics, 13(2), 385-390. 
Khattry, B. (2003). Trade Liberalization and the Fiscal Squeeze: Implications for Public Investment. Development and Change, 34(3), 401-424.

Khattry, B., and Rao, J.M. (2002) Fiscal Faux Pas?: An analysis of the revenue implications of trade liberalization, World Development 30 (8), 1431-1444.

Kneller, R., Morgan, C. W., and Kanchanahatakij, S. (2008). Trade Liberalisation and Economic Growth. World Economy, 31(6), 701-719.

Kreickemeier, U., and Raimondos-Møller, P. (2008). Tariff-tax reforms and market access. Journal of Development Economics, 87(1), 85-91.

Lee, Y., and Gordon, R. (2005). Tax Structure and Economic Growth. Journal of Public Economics, 89, 1027-1043.

Lu, C-H. (2015). Fiscal policies, frictional labor market, and endogenous growth. Journal of Macroeconomics, 46, 315-327.

Marshall, M.G., Gurr, T.R., and Jaggers, K. (2018). Polity IV Project: Political Regime Characteristics and Transitions, 1800-2017. Centre for Systemic Peace: Vienna, VA.

McNabb, K. (2018). Tax Structures and Economic Growth: New Evidence from the Government Revenue Dataset. Journal of International Development, 30(2), 173-205.

Melitz, M.J. (2003). The impact of trade on intra-industry reallocations and aggregate industry productivity. Econometrica, 71(6), 1695-1725.

Michael, S. M., Hatzipanayotou, P., and Miller, S. M. (1993). Integrated Reforms of Tariffs and Consumption Taxes. Journal of Public Economics, 52(3), 417-428.

Miller, S.M., and Russek, F.S. (1997). Fiscal Structures and Economic Growth: International Evidence. Economic Inquiry, 35(3), 603-613.

Myles, G. D. (2000). Taxation and economic growth. Fiscal Studies, 21, 141-168.

Naito, T. (2006). Growth, revenue, and welfare effects of tariff and tax reform: Win-win-win strategies. Journal of Public Economics, 90(6-7), 1263-1280.

Naito, T., and Abe, K. (2008). Welfare- and revenue-enhancing tariff and tax reform under imperfect competition. Journal of Public Economic Theory, 10, 1085-1094.

Nickell, S. (1981). Biases in Dynamic Models with Fixed Effects. Econometrica, 49(6), 1417-1426. of Economics, 70, 6-94.

Onafowora, O. A. and Owoye, O. (1998). Can Trade Liberalization Stimulate Economic Growth in Africa? World Development, 26(3), 497-506.

Padovano, F., and Galli, E. (2001). Tax Rates and Economic Growth in the OECD Countries (1950-1990). Economic Inquiry, 39, 44-57. 
Panagariya, A. (2004). Miracles and Debacles: In Defence of Trade Openness. World Economy, 27(8), 1149-1171.

Piketty, T., Saez, E., and Stantcheva, S. (2011). Optimal Taxation of Top Labor Incomes: A Tale of Three Elasticities. American Economic Journal: Economic Policy 2014, 6(1), 230-271

Romer, C. D., and Romer, D. H. (2010). The macroeconomic effects of tax changes: Estimates based on a new measure of fiscal shocks. The American Economic Review, 100, 763-801.

Romer, P., 1990. Endogenous Technological Change. Journal of Political Economy, 98, S71-102.

Roodman, D. M. (2009). A note on the theme of too many instruments, Oxford Bulletin of Economic and Statistics, 71 (1), 135-158.

Singh, T. (2010). Does international trade cause economic growth? A Survey. The World Economy 33(11), 1517-1564.

Solow, R. M. (1956). A contribution to the theory of economic growth. The Quarterly Journal of Economics, 70, 6-94.

Squalli, J., and Wilson, K. (2011). A New Measure of Trade Openness. The World Economy, 34(10), 1745-1770.

Swan, T. W. (1956). Economic growth and capital accumulation. Economic Record, 32, 334-361.

Waglé, S. (2011). Coordinating Tax Reforms in the Poorest Countries: Can Lost Tariffs be Recouped? Policy Research Working Paper 5919. The World Bank, Washington, DC.

Windmeijer, F. (2005). A finite sample correction for the variance of linear efficient two-step GMM estimators. Journal of Econometrics, 126(1), 25-51.

Yanikkaya, H. (2003). Trade openness and economic growth: a cross-country empirical investigation. Journal of Development Economics, 72(1), 57-89. 
Figures

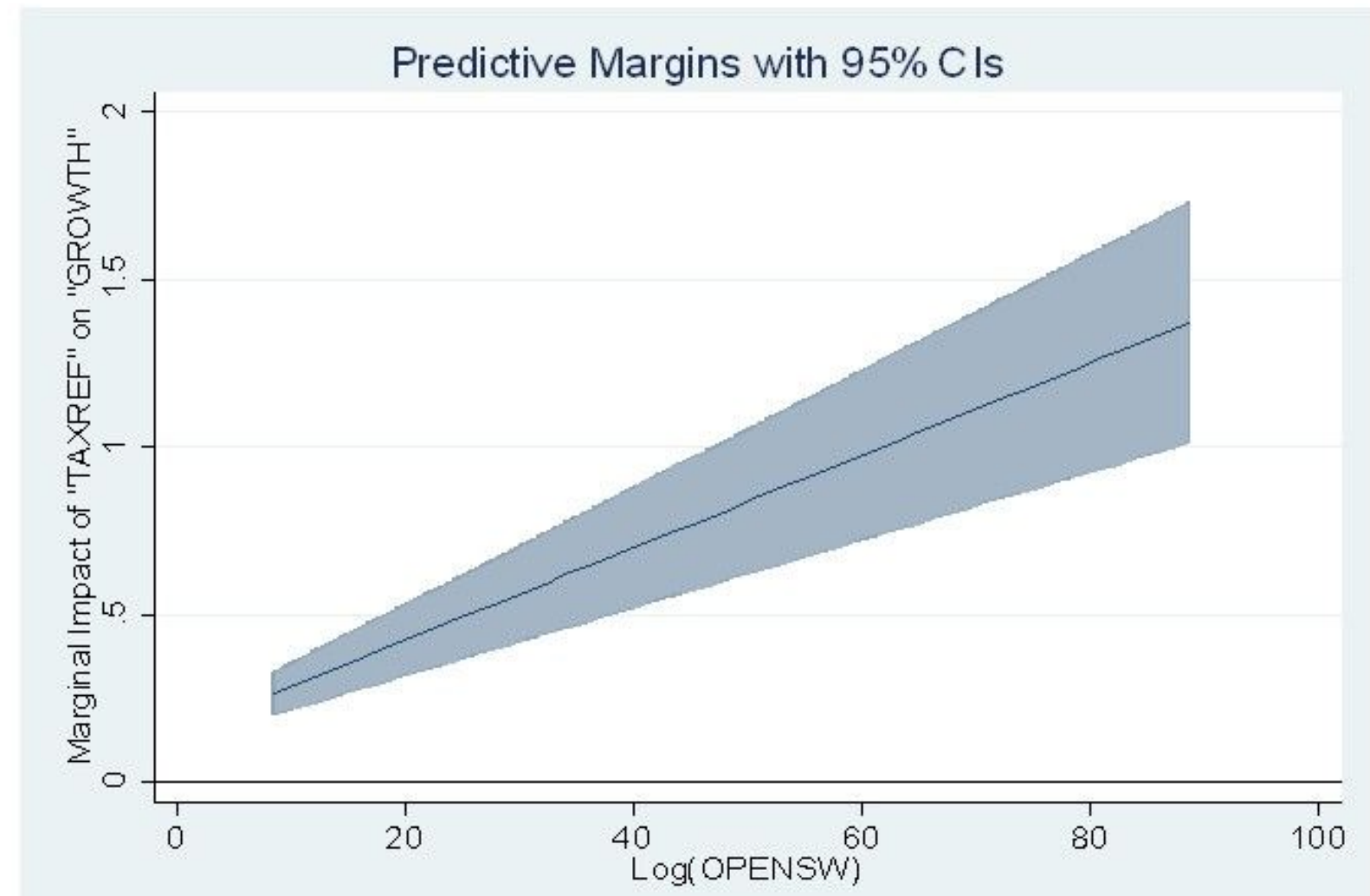

Source: Autbor

\section{Figure 1}

Marginal Impact of "TAXREF" on "GROWTH", for varying levels of trade openness ("OPENSW") 


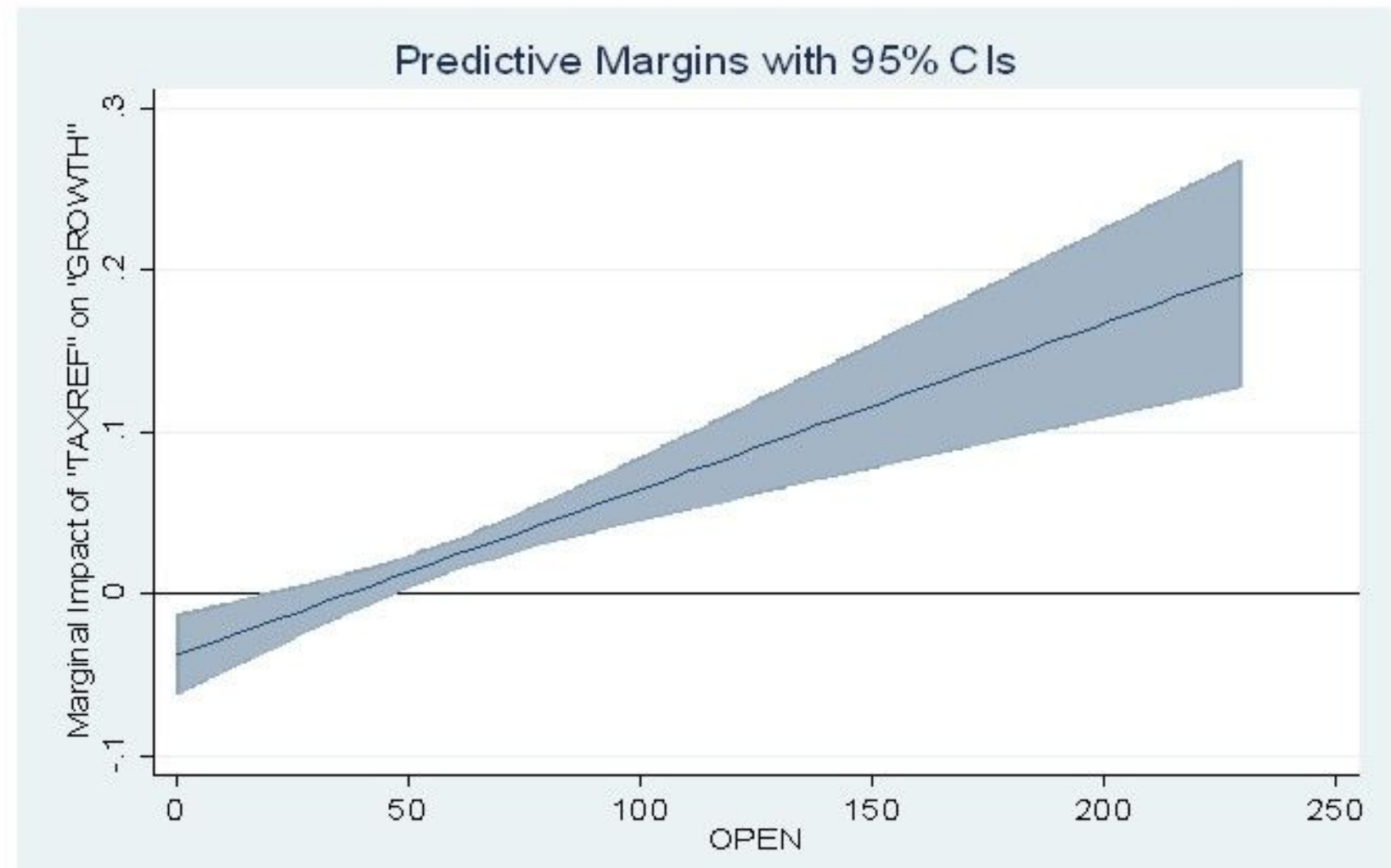

Source: Autbor

Figure 2

Marginal Impact of "TAXREF" on "GROWTH", for varying levels of trade openness ("OPEN") 


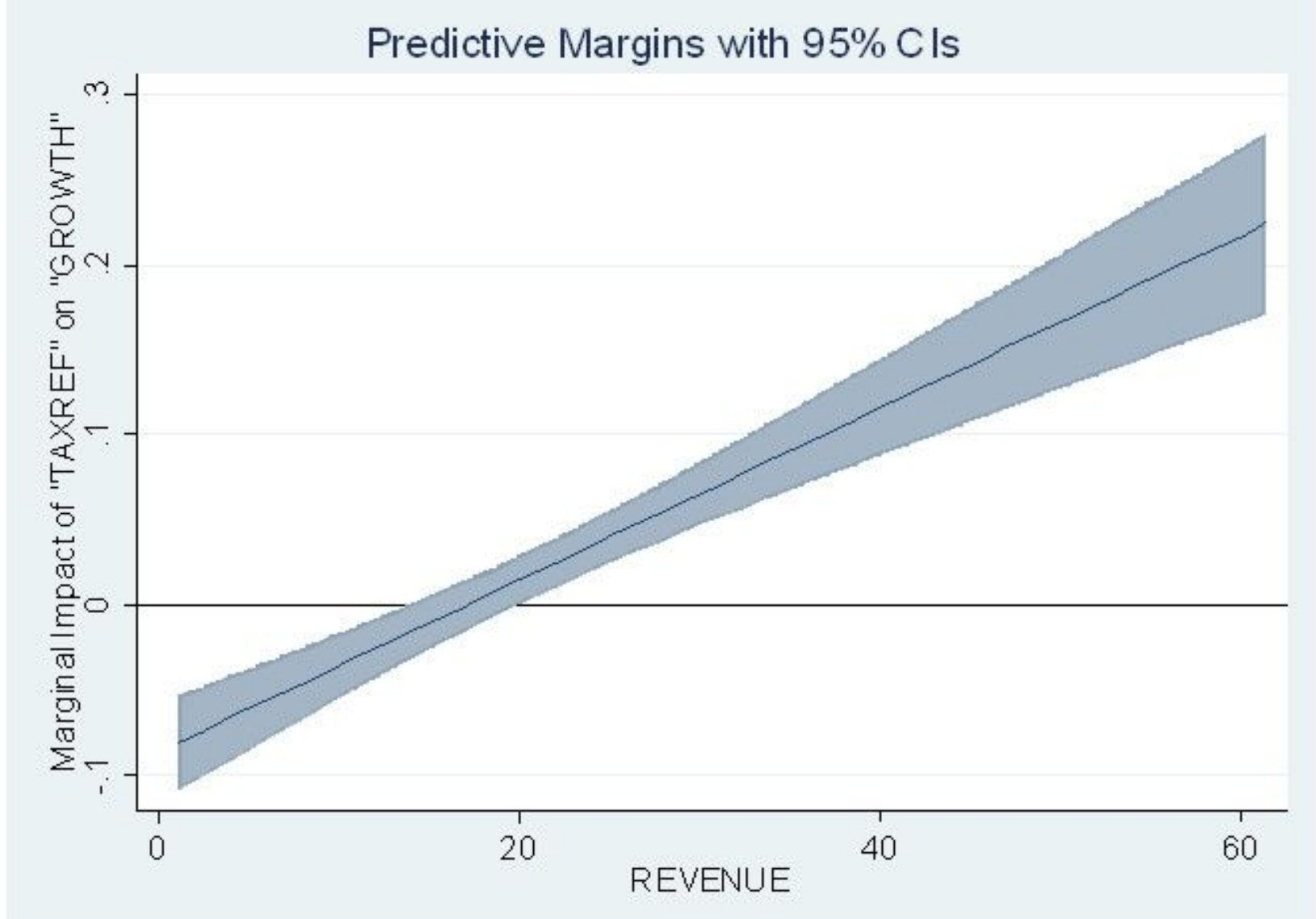

Source: Autbor

Figure 3

Marginal Impact of "TAXREF" on "GROWTH", for varying levels of total public revenue share of GDP

\section{Supplementary Files}

This is a list of supplementary files associated with this preprint. Click to download.

- Appendices.docx 